\title{
Red Dynamite
}


A volume in the series

Religion and American Public Life

edited by R. Laurence Moore and Darryl Hart 


\section{Red Dynamite}

\section{Creationism, Culture Wars, and Anticommunism in America}

Carl R. Weinberg

Cornell University Press

ITHACA AND LONDON 


\section{Copyright $\odot 2021$ by Cornell University}

Publication of this open monograph was the result of Indiana University's participation in TOME (Toward an Open Monograph Ecosystem), a collaboration of the Association of American Universities, the Association of University Presses, and the Association of Research Libraries. TOME aims to expand the reach of long-form humanities and social science scholarship including digital scholarship. Additionally, the program looks to ensure the sustainability of university press monograph publishing by supporting the highest quality scholarship and promoting a new ecology of scholarly publishing in which authors' institutions bear the publication costs. See http://openmonographs.org/.

Funding from Indiana University made it possible to open this publication to the world.

This work was (partially) funded by the Office of the Vice Provost of Research and the IU Libraries.

The text of this book is licensed under a Creative Commons AttributionNonCommercial-NoDerivatives 4.0 International License (CC BY-NCND 4.0): https:// creativecommons.org/licenses/by-nc-nd/4.0/. To use this book, or parts of this book, in any way not covered by the license, please contact Cornell University Press, Sage House, 512 East State Street, Ithaca, New York 14850. Visit our website at cornellpress.cornell.edu.

First published 2021 by Cornell University Press

Library of Congress Cataloging-in-Publication Data

Names: Weinberg, Carl R., 1962- author.

Title: Red dynamite : creationism, culture wars, and anticommunism in America / Carl R. Weinberg.

Description: Ithaca [New York] : Cornell University Press, 2021. I Series: Religion and American public life I Includes bibliographical references and index.

Identifiers: LCCN 2021020719 (print) | LCCN 2021020720 (ebook) | ISBN 9781501759291 (paperback) | ISBN 9781501759307 (pdf) | ISBN 9781501759314 (epub)

Subjects: LCSH: Anti-communist movements-United States-History20th century. I Anti-communist movements-United States-History21st century. I Evolution (Biology)—Study and teaching-Political aspects—United States. I Evolution (Biology)—Political aspects—United States.

Classification: LCC E743.5 .W34 2021 (print) I LCC E743.5 (ebook) I

DDC 324.1/3-dc23

LC record available at https://lccn.loc.gov/2021020719

LC ebook record available at https://lccn.loc.gov/2021020720 
For Beth 
